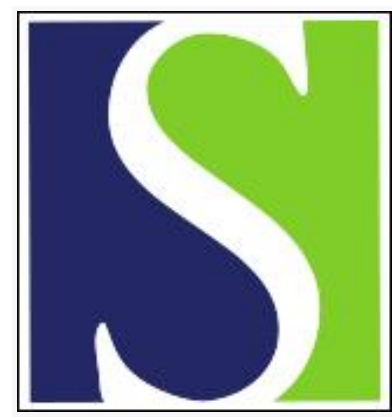

Scand J Work Environ Health 2013;39(6):618-630

https://doi.org/10.5271/sjweh.3358

Published online: 22 Mar 2013, Issue date: 01 Nov 2013

Chromosomal damage among medical staff occupationally exposed to volatile anesthetics, antineoplastic drugs, and formaldehyde

by Musak L, Smerhovsky Z, Halasova E, Osina O, Letkova L, Vodickova L, Polakova V, Buchancova J, Hemminki K, Vodicka P

We report significantly increased chromosomal damage among medical staff occupationally exposed to various genotoxic compounds in several medical professions. Potentially harmful exposures in hospital environment represent considerable health risk, since chromosomal aberrations have been found to be predictive of cancer risk, and an association between chromosomal damage and cancer risk has been shown.

Affiliation: Department of Molecular Biology of Cancer, Institute of Experimental Medicine Academy of Sciences of the Czech Republic, Videnska 1083, 14200 Prague, Czech Republic. pvodicka@biomed.cas.cz

Key terms: anesthesiologist; antineoplastic drug; chromosomal aberration; chromosomal damage; formaldehyde; health risk; hospital staff; medical staff; occupational exposure; occupational exposure; oncological department; pathological department; volatile anesthetic

This article in PubMed: www.ncbi.nlm.nih.gov/pubmed/23525098

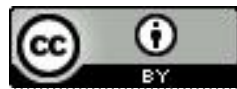




\title{
Chromosomal damage among medical staff occupationally exposed to volatile anesthetics, antineoplastic drugs, and formaldehyde
}

\author{
by Ludovit Musak, PhD, ${ }^{1}$ Zdenek Smerhovsky, PhD, ${ }^{2}$ Erika Halasova, PhD, ${ }^{3}$ Oto Osina, PhD, ${ }^{1}$ Lucia \\ Letkova, MSc, ${ }^{4}$ Ludmila Vodickova, PhD, ${ }^{5,6}$ Veronika Polakova, PhD, ${ }^{5,6}$ Janka Buchancova, MD, PhD, ${ }^{7}$ \\ Kari Hemminki, MD, PhD, 8 Pavel Vodicka, PhD ${ }^{5,6}$
}

\begin{abstract}
Musak L, Smerhovsky Z, Halasova E, Osina 0, Letkova L, Vodickova L, Polakova V, Buchancova J, Hemminki K, Vodicka P. Chromosomal damage among medical staff occupationally exposed to volatile anesthetics, antineoplastic drugs, and formaldehyde. Scand J Work Environ Health. 2013;39(6):618-630. doi:10.5271/sjweh.3358
\end{abstract}

\begin{abstract}
Objectives Structural chromosomal aberrations in blood lymphocytes represent a biomarker for cellular damage caused by genotoxic carcinogens and are an indicator of increased cancer risk. We evaluated the association between frequencies of total chromosomal aberrations, chromatid- and chromosome-type aberrations, and occupational exposures to volatile anesthetics, antineoplastic agents, and formaldehyde among 601 medical professionals.
\end{abstract}

Methods Chromosomal damage among exposed individuals and unexposed controls was determined by conventional cytogenetic analysis. We used binary logistic regression to evaluate the effects of workplace exposures and major confounders on chromosomal damage.

Results Significantly higher frequencies of total chromosomal, chromatid-type and chromosome-type aberrations were observed among subjects occupationally exposed to volatile anesthetics, antineoplastic agents, and formaldehyde compared to age- and sex-matched controls $(\mathrm{P}<0.0001)$. The risk of an increased frequency of chromosomal aberrations was associated with exposure to anesthetics [odds ratio (OR) 3.9, 95\% confidence interval (95\% CI) 2.7-5.8], cytostatics (OR 2.7, 95\% CI 1.9-3.9), and formaldehyde (OR 1.7, 95\% CI 1.1-2.7). No other covariate contributed significantly to the model. Chromatid- and chromosome-type aberrations were associated with exposure to anesthetics and cytostatics without any contribution of other variables. Stratified data analysis showed the risk of increased chromosomal aberrations among non-smoking female nurses and physicians exposed to anesthetics, cytostatics and, partially, formaldehyde. Chromatid and chromosome exchanges were significantly higher in the exposed groups than among controls.

Conclusion Our findings indicate that the presence of genotoxic compounds in operating rooms, oncological units, and pathological departments results in a significant increase of chromosomal damage (impair of chromosomal integrity) among medical workers employed in these facilities.

Key terms anesthesiologist; chromosomal aberration; health risk; hospital staff; occupational exposure; oncological department; pathological department.

Medical personnel in specialized wards may be exposed to various genotoxic and carcinogenic agents, including volatile anesthetics, antineoplastic agents, and formaldehyde. The mutagenic and carcinogenic effects of these agents have been frequently discussed (1-13) as they pose a potential genotoxic burden and health problems for a considerable number of individuals in various branches of medicine. Consequently, a conclusive assessment of chromosomal damage among medical personnel is of particular importance.

1 Clinic of Occupational Medicine \& Toxicology, Jessenius Faculty of Medicine, Comenius University and University Hospital Martin, Martin, Slovakia.

$22^{\text {nd }}$ Medical Faculty, Charles University, Prague, Czech Republic.

3 Department of Medical Biology, Jessenius Faculty of Medicine, Comenius University, Martin, Slovakia.

4 Department of Medical Biochemistry, Jessenius Faculty of Medicine, Comenius University, Martin, Slovakia.

5 Institute of Experimental Medicine, Academy of Sciences of the Czech Republic, Prague, Czech Republic.

6 Institute of Biology and Medical Genetics, First Medical Faculty, Charles University, Prague, Czech Republic.

7 Department of Public Health, Jessenius Faculty of Medicine, Comenius University, Martin, Slovakia.

8 Department of Molecular Genetic Epidemiology, German Cancer Research Centre Heidelberg (DKFZ), Heidelberg, Germany.

Correspondence to: Pavel Vodicka, Department of Molecular Biology of Cancer, Institute of Experimental Medicine Academy of Sciences of the Czech Republic, Videnska 1083, 14200 Prague, Czech Republic. [E-mail: pvodicka@biomed.cas.cz] 
Anesthesiologists form an inseparable part of operation teams with occupational exposure to volatile anesthetics. Presently, the most frequently used anesthetics include sevoflurane, isoflurane, desflurane, and entrane, all of which have gradually replaced the more toxic halothane. Describing isoflurane- and halothane-induced elevation of DNA damage and degradation due to cell death in peripheral human lymphocytes (PBL) in vitro, the study of Jaloszynski et al (11) is one of the first on the possible genotoxicity of anesthetics. Cellular DNA damage increased after exposure to both desflurane and halothane (12). In the recent study of Rozgaj et al (14), increased levels of DNA damage were reported among anesthesiologists exposed to the anesthetic gases sevoflurane, isoflurane, and nitrous oxide. The authors also recorded a three-fold increase in the frequency of micronuclei, representing chromosomal damage (14). These findings are in accordance with the earlier data of Lewinska et al (15), who demonstrated a significant increase in micronucleus frequency in PBL among nurses exposed to nitrous oxide. A putative mode of action of isoflurane could be the formation of reactive trifluoroacetyl ester, resulting in modification of N7-position of guanine. However, induction of oxidative DNA damage has also been postulated for isoflurane, sevoflurane, and nitrous oxide (16-18).

Although the hazard is well known, employees in oncological units may experience occupational exposure to low doses of antineoplastic agents. The majority of cytostatics are genotoxic, either directly or following biotransformation into electrophilic intermediates (19), or damage the genetic material by secondary mechanisms. The International Agency for Research on Cancer (IARC) has classified many antineoplastic agents as class 1 human carcinogens (eg, cyclophosphamide, etoposide, busulfan, melfalan), class $2 \mathrm{~A}$ probably carcinogenic to humans (eg, azacitidine, cisplatin, doxorubicine) or class $2 \mathrm{~B}$ possibly carcinogenic to humans (bleomycin, dacarbazine, mitoxantrone, mitomycin) (20). Occupational exposure to antineoplastic agents has been shown to result in an increased frequency of total chromosomal aberrations (CATot) in PBL, as documented by a number of studies (2, 21-26). Interestingly, nurses occupationally exposed to antineoplastic drugs showed an elevated level of not only chromatid-type aberrations (CTA) (induced by most chemical clastogens), but also chromosome-type aberrations (CSA), such as chromosome breaks and dicentric chromosomes, which is typical of radiation exposure (23).

Formaldehyde is used in histopathology laboratories worldwide as a fixative and tissue preservative. Although the IARC has classified formaldehyde as a class 1 carcinogen (13), only a few studies have explored its genotoxic effects in expected target organs, ie, upper respiratory tract (27). However, significant associations between occupational exposure to formaldehyde and the frequencies of CATot, sister chromatid exchanges (SCE) and micronuclei in PBL of formaldehyde-exposed individuals have been reported (28). Despite the fact that only scant concentration of formaldehyde reaches the blood cells, long-term, cumulative occupational exposure may underlie the cytogenetic effects of formaldehyde.

In this study, we quantified the association between the occupational exposure of physicians and nurses employed in operating rooms (exposure to volatile anesthetics), oncologic units (exposure to antineoplastic agents), and pathological departments (exposure to formaldehyde) and the occurrence of chromosomal aberrations (CA) compared with sex- and age-matched controls. This is an important issue, since the abovementioned compounds are classified as proven (formaldehyde and cyclophosphamide, for instance) or potential human carcinogens $(13,29,30)$ and the level of CA is considered to be predictive of cancer risk (31-33).

\section{Methods}

\section{Study population}

The subjects were recruited in a university hospital, a central military hospital, a faculty hospital and seven regional hospitals, all located in Central Slovakia. Table 1 summarizes the study subjects' characteristics, including main confounders. Briefly, the studied medical personnel consisted of anesthesiologists occupationally exposed to volatile anesthetics in operating rooms during the administration of volatile anesthetics as a part of complete anesthesia $(\mathrm{N}=247)$, staff from specialized oncologic units exposed to antineoplastic agents $(\mathrm{N}=249)$, and pathologists from pathologic anatomy departments $(\mathrm{N}=105)$. The control group consisted of healthy medical staff from the university hospital and central military hospital with no apparent exposure to genotoxic agents $(\mathrm{N}=250)$. The group of anesthesiologists consisted of 139 anesthesiological nurses and 108 physicians-anesthesiologists, the staff from oncology units comprised 213 nurses (including 12 technicians working with cytostatic waste) and 36 physicians, and the departments of pathologic anatomy employees totaled 69 laboratory technicians and 36 pathologists. Blood sampling and data collections were conducted during 2006-2011. Only those subjects apparently healthy at the time of sampling were enrolled in the study. Additionally, individuals with close relatives with any malignant diseases were excluded. Otherwise, no other exclusion criteria were imposed. There was no statistical difference in age between the genders. 
Table 1. Characteristics of medical workers occupationally exposed to volatile anesthetics, antineoplastic agents, and formaldehyde compared to unexposed control individuals.

\begin{tabular}{|c|c|c|c|c|c|c|c|c|c|c|c|c|c|c|c|c|c|c|c|c|}
\hline & \multicolumn{5}{|c|}{ Volatile anesthetics ( $\mathrm{N}=247$ ) } & \multicolumn{5}{|c|}{ Antineoplastic agents $(\mathrm{N}=249)$} & \multicolumn{5}{|c|}{ Formaldehyde $(\mathrm{N}=105)$} & \multicolumn{5}{|c|}{ Control $(\mathrm{N}=250)$} \\
\hline & $\mathrm{N}$ & $\%$ & Mean & SD & Range & $\mathrm{N}$ & $\%$ & Mean & SD & Range & $\mathrm{N}$ & $\%$ & Mean & SD & Range & $\mathrm{N}$ & $\%$ & Mean & SD & Range \\
\hline Age (years) & & & 38.0 & 9.0 & & & & 39.2 & 9.6 & & & & 41.7 & 9.6 & & & & 36.2 & 10.6 & \\
\hline $\begin{array}{l}\text { Exposure } \\
\text { (years) }\end{array}$ & & & 12.8 & 9.6 & & & & 8.5 & 8.6 & & & & 14.7 & 10.4 & & & & 10.9 & 9.5 & \\
\hline Men & 47 & 19 & & & & 21 & 8.5 & & & & 23 & 22 & & & & 27 & 11 & & & \\
\hline Women & 200 & 81 & & & & 228 & 91.5 & & & & 82 & 78 & & & & 223 & & & & \\
\hline Smokers & 74 & 30 & & & & 73 & 29.3 & & & & 29 & 27.6 & & & & 48 & 19.2 & & & \\
\hline Non-smokers & 173 & 70 & & & & 176 & 70.7 & & & & 76 & 72.4 & & & & 202 & 80.8 & & & \\
\hline $\begin{array}{l}\text { Number of } \\
\text { cigerettes/day }\end{array}$ & & & & & & & & & & & & & & & & & & & & \\
\hline Men & 15 & & 13.2 & & $2-40$ & 11 & & 12.3 & & $5-20$ & 13 & & 12.3 & & $5-20$ & 8 & & 8.5 & & $3-20$ \\
\hline Women & 59 & & 8.8 & & $1-20$ & 62 & & 10.0 & & $1-20$ & 16 & & 10.6 & & $2-20$ & 40 & & 9.9 & & $5-20$ \\
\hline Job category & & & & & & & & & & & & & & & & & & & & \\
\hline Physicians & 108 & 43.7 & & & & 36 & 14.5 & & & & 36 & 34.3 & & & & 47 & 18.8 & & & \\
\hline Nurses & 139 & 56.3 & & & & 213 & 85.5 & & & & 69 & 65.7 & & & & 203 & 81.2 & & & \\
\hline
\end{tabular}

All individuals studied completed a questionnaire regarding the mode and duration of exposure, job category, various exogenous factors (such as smoking, drug usage, exposure to X-ray radiation, alcohol consumption, and dietary habits) prior to blood collection and provided a written consent to be included into the study. The present study adheres to all principles of personnel data protection and was conducted according to the Helsinki Declaration. The local Ethical Committee of the Jessenius Medical Faculty approved the study design.

\section{Estimation of the exposure}

Exposure to volatile anesthetics was estimated by ambient air measurements in operating rooms of a hospital. The permissible average exposure limit (PEL) of sevoflurane and isoflurane is $10 \mathrm{ppm}\left(80 \mathrm{mg} / \mathrm{m}^{3}\right)$, with a short-term concentration not exceeding $20 \mathrm{ppm}(150$ $\mathrm{mg} / \mathrm{m}^{3}$ ). The average determined concentration of sevoflurane and isoflurane (based on 2 measurements at 24 different places in various operating rooms at the University Hospital) was $200.3 \mathrm{mg} / \mathrm{m}^{3}$ (range $64.2-483.9$ $\mathrm{mg} / \mathrm{m}^{3}$ ). During the administration of volatile anesthetics (as a part of complete anesthesia in operating rooms), the nominal amounts of 1501 of sevoflurane and 21 of isoflurane were used in 2011. Exposure to $>40$ antineoplastic agents could be estimated only on the basis of annual use of active compounds in 2011; the most frequently used were cyclophosphamide $(930 \mathrm{~g})$, cytarabin (520 g), rituximab (420 g), fluoruracil (270 g), and ifosfamide $(270 \mathrm{~g})$. The medical staff wore protective clothing and gloves, and the preparation of cytostatics took place in laminary flow or fume hoods. The concentration of formaldehyde at the department of pathologic anatomy, measured once a year, was $0.32 \mathrm{mg} / \mathrm{m}^{3}$ (range $0.14-0.66 \mathrm{mg} / \mathrm{m}^{3}$ ), which is below the maximum accepted ambient air concentrations of formaldehyde in
Slovakia (average concentration of $0.37 \mathrm{mg} / \mathrm{m}^{3}$, shortterm concentration $0.74 \mathrm{mg} / \mathrm{m}^{3}$ ).

\section{Cytogenetic analysis}

The peripheral blood sampling by venepuncture was performed as a part of specialized medical examinations between 2009-2011. The methodology for cytogenetic analysis has been described earlier $(33,34)$ and was in accordance with existing guidelines (35). Briefly, peripheral blood lymphocytes stimulated to grow by phytohemagglutinin were cultured for 48 hours. Two microscopists conducted microscopical analysis (each evaluating half of the 100 mitoses scored per subject) in a double-blind fashion on coded slides (codes were broken only after the end of the analysis of the whole subgroup/hospital). The frequency of CATot and the constituent CTA and CSA were evaluated. Inter- and intra-arm exchanges of CTA and CSA (mainly dicentrics and centric rings) were also analyzed (36).

\section{Statistical analysis}

Univariate statistics for the cytogenetic endpoints of interest (CATot, CTA, and CSA) and selected covariates were calculated. Furthermore, histograms to describe the distributions of CATot, CTA, and CSA were formulated. Differences in the frequencies of CA among the different occupational groups were tested by non-parametric Mann-Whitney U-test and Kruskal-Wallis test.

In the next step, the subjects were classified according to the median of CATot distribution as either low (frequency $<2 \%$ ) or high (frequency $\geq 2 \%$ ). This arbitrary cut-off point was chosen on the basis of long-term experience with this kind of biological monitoring in the Czech and Slovak Republics (37). Regarding CTA and CSA, the subjects were classified as having low $(<1 \%)$ 
or high $(\geq 1 \%)$ frequency, and, in the case of chromatid and chromosome exchanges, the subjects were classified according to the presence or absence of these chromosomal categories. Stratified data analysis was employed to evaluate relationships between frequencies of categorized cytogenetic endpoints and variables describing occupational exposures and potential confounders, such as job category ( $1=$ physicians, $0=$ nurses), smoking $(1=$ yes, $0=$ no $)$ and gender $(1=$ man, $0=$ women $)$. Crude odds ratios (OR) and OR adjusted for gender, job, and smoking specific strata are reported with $95 \%$ confidence intervals $(95 \% \mathrm{CI})$. The differences between the frequencies of evaluated cytogenetic endpoints were tested by Chi-square test. The adjusted OR were calculated by binary logistic regression where gender, job, smoking, and age (calendar years) of the subjects were included as variables.

The statistical analysis was performed by SPSS analytical package version 16.0 (SPSS Inc, Chicago, IL, USA) and SAS JMP 8 (SAS Institute, Cary, NC, USA).

\section{Results}

The distributions of CATot, CTA, and CSA among all individuals investigated are presented in figures $1 \mathrm{~A}, \mathrm{~B}$ and $\mathrm{C}$. We observed significantly higher frequencies of CATot, CTA, and CSA in all groups of medical workers with occupational exposure as compared to the unexposed medical employees, and these differences were also seen in the distributions of the cells with CATot, CTA, and CSA (Figure 1a, $\mathrm{b}$ and $\mathrm{c}$, respectively; $\mathrm{P}<0.0001$ by Kruskal-Wallis). Table 2 presents the median, minimal, and maximal values and percentiles of the evaluated cytogenetic endpoints. Significantly higher frequencies of CATot were separately observed in all exposed groups in comparison with the controls $(\mathrm{P}<0.0001$, Mann-Whitney U-test). CTA and CSA were higher in subjects exposed to volatile anesthetics $(\mathrm{P}<0.001$ and $\mathrm{P}<0.0001$, respectively, Mann-Whitney U-test), cytostatics $(\mathrm{P}<0.0001$ and $\mathrm{P}<0.0001$, respectively, Mann-Whitney U-test), and formaldehyde $(\mathrm{P}<0.01$ and $\mathrm{P}<0.01$, respectively, MannWhitney U-test) as compared to the control subjects.

When we analyzed the categorized frequencies of $\mathrm{CA}$, the stratified analyses revealed that there were generally consistent effects of occupational exposures over the strata. The few inconsistencies observed could be explained by the lack of data in some strata. The stratified analyses, therefore, did not suggest the presence of biologically significant interactions. Furthermore, the comparison of the adjusted and crude estimates of OR did not suggest the presence of a confounding effect and it may be concluded that job, smoking, gender, and age were not important confounders in any presented model.
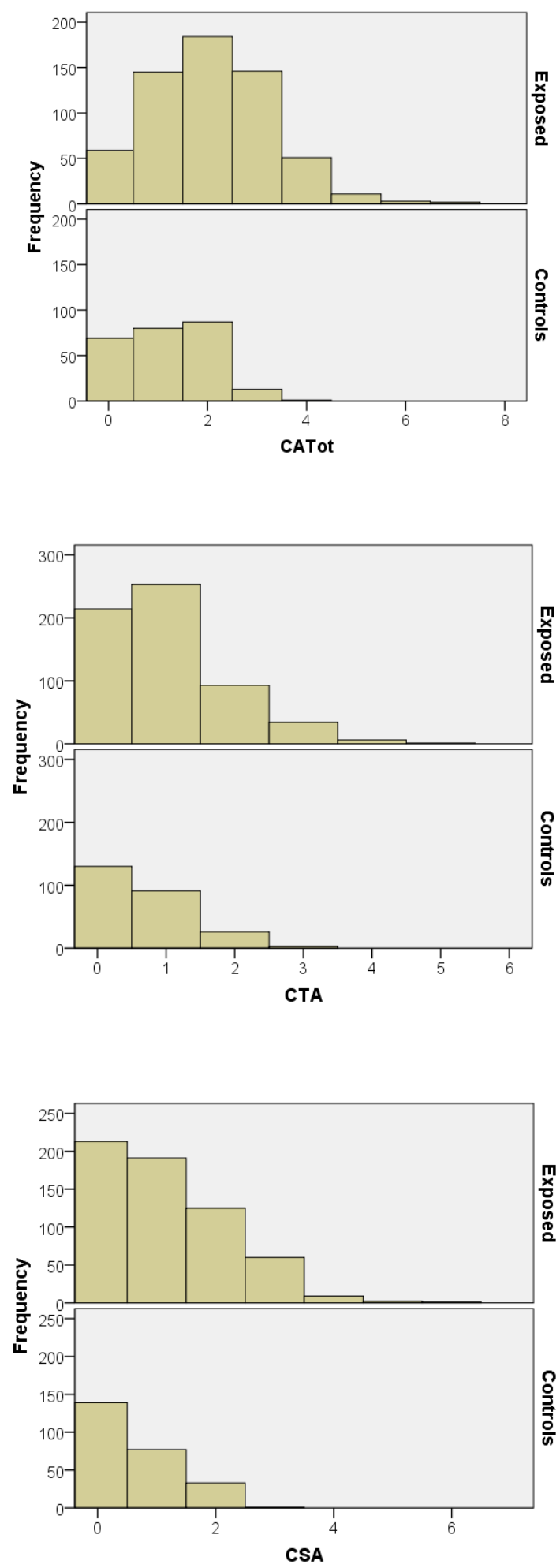

Figure 1. Distribution of the number of cells with total chromosomal aberrations (CATot), chromatid-type aberrations (CTA), and chromosometype aberrations (CSA) in peripheral blood lymphocytes of the exposed (upper diagram) and control (lower diagram) individuals investigated. 
Table 2. Median (50 ${ }^{\text {th }}$ percentile), interquartile range $\left(25^{\text {th }}\right.$ and $75^{\text {th }}$ percentiles), and minimum and maximum values of distributions of the number of cells (per 100 cells) with any type of total chromosomal aberrations (CATot), chromatid-type aberrations (CTA), and chromosome-type aberrations (CSA) among medical workers occupationally exposed to volatile anesthetics, antineoplastic agents, and formaldehyde compared to unexposed control individuals.

\begin{tabular}{|c|c|c|c|c|c|c|}
\hline \multirow{3}{*}{$\begin{array}{l}\text { Group of } \\
\text { subjects and } \\
\text { chromosomal } \\
\text { category }\end{array}$} & \multirow[t]{3}{*}{$\mathrm{N}$} & \multicolumn{5}{|c|}{ Number of cells with CATot/100 cells } \\
\hline & & \multirow[t]{2}{*}{ Min } & \multicolumn{3}{|c|}{ Percentile } & \multirow[t]{2}{*}{ Max } \\
\hline & & & $25^{\text {th }}$ & $\begin{array}{c}50^{\text {th }} \\
\text { (median) }\end{array}$ & $75^{\text {th }}$ & \\
\hline \multicolumn{7}{|l|}{ Anesthetics } \\
\hline CATot & 247 & 0 & 1 & 2 & 3 & 7 \\
\hline CTA & 247 & 0 & 0 & 1 & 1 & 4 \\
\hline CSA & 247 & 0 & 0 & 1 & 2 & 6 \\
\hline \multicolumn{7}{|l|}{$\begin{array}{l}\text { Antineoplastic } \\
\text { drugs }\end{array}$} \\
\hline CATot & 249 & 0 & 1 & 2 & 3 & 7 \\
\hline CTA & 249 & 0 & 0 & 1 & 2 & 5 \\
\hline CSA & 249 & 0 & 0 & 1 & 2 & 3 \\
\hline \multicolumn{7}{|l|}{ Formaldehyde } \\
\hline CATot & 105 & 0 & 1 & 2 & 3 & 5 \\
\hline CTA & 105 & 0 & 0 & 1 & 1 & 3 \\
\hline CSA & 105 & 0 & 0 & 1 & 2 & 3 \\
\hline \multicolumn{7}{|l|}{ Controls } \\
\hline CATot & 250 & 0 & 0 & 1 & 2 & 4 \\
\hline CTA & 250 & 0 & 0 & 0 & 1 & 3 \\
\hline CSA & 250 & 0 & 0 & 0 & 1 & 3 \\
\hline \multicolumn{7}{|l|}{ Total } \\
\hline CATot & 851 & 0 & 1 & 2 & 3 & 7 \\
\hline CTA & 851 & 0 & 0 & 1 & 1 & 5 \\
\hline CSA & 851 & 0 & 0 & 1 & 2 & 6 \\
\hline
\end{tabular}

When we focused on the binary logistic models presented in tables $3 \mathrm{~A}, \mathrm{~B}$, and $\mathrm{C}$, we observed that the risk of increased frequency of CATot was associated with occupational exposure to anesthetics (OR 3.9, 95\% CI 2.7-5.8), cytostatics (OR 2.7, 95\% CI 1.9-3.9), and formaldehyde (OR 1.7, 95\% CI 1.1-2.7). No other covariate contributed significantly to the model. When we analyzed the effects of the variables studied on the categorized frequency of CTA, we observed that this cytogenetic endpoint was associated with exposure to anesthetics (OR 1.8, 95\% CI 1.3-2.6) and cytostatics (OR 2.6, 95\% CI 1.8-3.8). No other variable contributed significantly to this model. A similar finding was also recorded for CSA. We observed significant associations between CSA and anesthetics (OR 3.8, 95\% CI 2.5-5.6) and cytostatics (OR 1.7, 95\% CI 1.2-2.4). The association between CSA and formaldehyde (OR 1.6, 95\% CI 1.0-2.5) was of borderline significance. Lack of data on chromatid exchanges prevented us from similar analyses on this rare aberration category. However, in the case of chromosomal exchanges, we found an association with formaldehyde (OR 2.6, 95\% CI 1.1-5.9). Analogically to other models, no other covariate contributed significantly to this model.

Closer investigation of the distribution of CATot within the strata revealed that a significant effect of occupational exposure to anesthetics, cytostatics, and partially formaldehyde (for female physicians) emerged among non-smoking female nurses and physicians (table $3 \mathrm{~A}$ ); exposure to anesthetics also increased CATot among smoking female nurses. There were not enough male nurses to perform a proper evaluation, but male physicians did not show exposure-related effects. We found a higher median value for CATot among smoking controls than non-smokers, but this difference was not significant. Among exposed individuals, no effect of smoking was apparent (data not shown). Various other exogenous factors (such as drug usage, exposure to X-rays or other types of ionizing radiation, alcohol consumption, and dietary habits) were not significantly different in the exposed groups as compared to the controls; thus they did not modulate the frequency of CATot (data not shown).

Stratified data analysis for CTA revealed significantly increased OR in association with exposure to anesthetics and cytostatics only among non-smoking female nurses (OR 3.0, 95\% CI 1.7-5.2 and OR 2.8, 95\% CI 1.7-4.5, respectively; table 3B). Stratified analysis for CSA (table 3C) revealed a significant association with exposure to anesthetics and cytostatics among non-smoking female nurses (OR 4.1, 95\% CI 2.3-7.4 and OR 1.8, 95\% CI $1.1-2.8$, respectively) and non-smoking female physicians exposed to anesthetics (OR 2.9, 95\% CI 1.1-7.9). Interestingly, the frequency of CSA was significantly associated with exposure to anesthetics also among smoking female nurses (OR 4.5, 95\% CI 1.7-11.5). A significant outcome for formaldehyde in the same group appeared less reliable due to the low number of subjects investigated (OR 4.2, 95\% CI 1.1-15.7).

An analysis of chromatid and chromosome inter-arm and intra-arm exchanges revealed that the percentage of subjects with exchanges, irrespective of their type, was significantly higher in all the exposed groups than controls (figure 2). Generally, chromatid-type exchanges were substantially less abundant than chromosome-type exchanges which included mainly dicentrics and centric rings. As apparent from figure 2, the highest proportion of both chromatid- and chromosome-type exchanges was recorded among individuals exposed to formaldehyde. This observation was further supported by binary logistic regression, where chromosome-type exchanges were associated with exposure to formaldehyde (OR 2.6, 95\% CI 1.1-5.9; $\mathrm{P}=0.024, \chi^{2}$ test) irrespective of any confounder recorded.

\section{Discussion}

In our study, we report significantly increased chromosomal damage among medical staff occupationally 
Table 3A. Binary logistic regression to describe relative risk of chromosomal aberrations (CA) for particular exposures in medical professions studied - stratified analysis for main confounders. Due to the low number of subjects, stratified results are not shown for smoking female physicians and for non-smoking or smoking male nurses. [OR=0dds ratio; $95 \% \mathrm{Cl}=95 \%$ confidence interval.]

\begin{tabular}{|c|c|c|c|c|c|c|}
\hline & \multicolumn{3}{|c|}{ Number of subjects } & \multirow[t]{3}{*}{ OR } & \multirow[t]{3}{*}{$95 \% \mathrm{Cl}$} & \multirow{3}{*}{$\begin{array}{c}\text { P-value } \\
\left(\mathrm{Chi}^{2}\right)\end{array}$} \\
\hline & \multicolumn{2}{|c|}{ Cells with CA/100 cell } & \multirow[t]{2}{*}{ Total } & & & \\
\hline & $\geq 1$ & $<1$ & & & & \\
\hline \multicolumn{7}{|l|}{ Female nurse (non-smoking) } \\
\hline Unexposed (controls) & 60 & 97 & 157 & 1.00 & & \\
\hline \multicolumn{7}{|l|}{ Exposed } \\
\hline Anesthetics & 70 & 20 & 90 & 5.66 & $3.13-10.23$ & 0.000 \\
\hline Cytostatics & 96 & 48 & 144 & 3.23 & $2.10-5.19$ & 0.000 \\
\hline Formaldehyde & 28 & 26 & 54 & 1.74 & $0.93-3.25$ & 0.081 \\
\hline Total & 254 & 191 & 445 & & & \\
\hline \multicolumn{7}{|l|}{ Female nurse (smoking) } \\
\hline Unexposed (controls) & 22 & 16 & 38 & 1.00 & & \\
\hline \multicolumn{7}{|l|}{ Exposed } \\
\hline Anesthetics & 36 & 7 & 43 & 3.74 & $1.33-10.52$ & 0.012 \\
\hline Cytostatics & 36 & 23 & 59 & 1.14 & $0.50-2.61$ & 0.760 \\
\hline Formaldehyde & 9 & 6 & 15 & 1.9 & $0.32-3.69$ & 0.889 \\
\hline Total & 103 & 52 & 155 & & & \\
\hline \multicolumn{7}{|c|}{ Female physician (non-smoking) } \\
\hline Unexposed (controls) & 7 & 19 & 26 & 1.00 & & \\
\hline \multicolumn{7}{|l|}{ Exposed } \\
\hline Anesthetics & 33 & 18 & 51 & 4.98 & $1.76-14.70$ & 0.002 \\
\hline Cytostatics & 16 & 7 & 23 & 6.20 & $1.79-21.46$ & 0.004 \\
\hline Formaldehyde & 7 & 4 & 11 & 4.75 & $1.60-21.36$ & 0.042 \\
\hline Total & 63 & 48 & 111 & & & \\
\hline \multicolumn{7}{|l|}{ Male physician (non-smoking) } \\
\hline Unexposed (controls) & 8 & 7 & 15 & 1.00 & & \\
\hline \multicolumn{7}{|l|}{ Exposed } \\
\hline Anesthetics & 17 & 12 & 29 & 1.24 & $0.35-4.35$ & 0.737 \\
\hline Cytostatics & 5 & 3 & 8 & 1.46 & $0.25-8.43$ & 0.673 \\
\hline Formaldehyde & 5 & 6 & 11 & 0.73 & $0.15-3.47$ & 0.692 \\
\hline Total & 35 & 28 & 63 & & & \\
\hline \multicolumn{7}{|l|}{ Male physician (smoking) } \\
\hline Unexposed (controls) & 1 & 4 & 5 & 1.00 & & \\
\hline \multicolumn{7}{|l|}{ Exposed } \\
\hline Anesthetics & 8 & 4 & 12 & 8 & $0.66-97.31$ & 0.103 \\
\hline Cytostatics & 1 & 1 & 2 & 4 & $0.12-136.96$ & 0.442 \\
\hline Formaldehyde & 7 & 6 & 13 & 4.67 & $0.40-53.95$ & 0.217 \\
\hline Total & 17 & 15 & 32 & & & \\
\hline \multicolumn{7}{|l|}{ Total data combined } \\
\hline Unexposed (controls) & 101 & 149 & 250 & 1.00 & & \\
\hline \multicolumn{7}{|l|}{ Exposed } \\
\hline Anesthetics & 177 & 70 & 247 & 3.73 & $2.56-5.43$ & 0.000 \\
\hline Cytostatics & 164 & 85 & 249 & 2.85 & $1.98-4.10$ & 0.000 \\
\hline Formaldehyde & 56 & 49 & 105 & 1.69 & $1.70-2.67$ & 0.026 \\
\hline Total & 498 & 353 & 851 & & & \\
\hline Binary logistic model & & & & & & \\
\hline Unexposed (controls) & & & & 1.00 & & \\
\hline Exposed (1 for yes) & & & & & & \\
\hline Anesthetics ( 1 for yes) & & & & 3.92 & $2.65-5.79$ & 0.000 \\
\hline Cytostatics ( 1 for yes) & & & & 2.71 & $1.88-3.92$ & 0.000 \\
\hline Formaldehyde (1 for yes) & & & & 1.70 & $1.60-2.72$ & 0.029 \\
\hline Gender (1 for man) & & & & 0.84 & $0.52-1.35$ & 0.476 \\
\hline Job (1 for physician) & & & & 0.79 & $0.54-1.16$ & 0.239 \\
\hline Smoking (1 for smoking) & & & & 1.21 & $0.87-1.69$ & 0.256 \\
\hline Age (years) & & & & 1.1 & $0.99-1.20$ & 0.380 \\
\hline
\end{tabular}


Table 3B. Binary logistic regression to describe relative risk of chromatid-type aberrations (CTA) for particular exposures in medical professions studied - stratified analysis for main confounders. Due to the low number of subjects, stratified results are not shown for smoking female physicians and for non-smoking or smoking male nurses. [OR=odds ratio; $95 \% \mathrm{Cl}=95 \%$ confidence interval.]

\begin{tabular}{|c|c|c|c|c|c|c|}
\hline & \multicolumn{3}{|c|}{ Number of subjects } & \multirow[t]{3}{*}{$\mathrm{OR}$} & \multirow[t]{3}{*}{$95 \% \mathrm{Cl}$} & \multirow{3}{*}{$\begin{array}{c}\text { P-value } \\
\left(\text { Chi }^{2}\right)\end{array}$} \\
\hline & \multicolumn{2}{|c|}{ Cells with $\mathrm{CA} / 100$ cell } & \multirow[t]{2}{*}{ Total } & & & \\
\hline & $\geq 1$ & $<1$ & & & & \\
\hline \multicolumn{7}{|l|}{ Female nurse (non-smoking) } \\
\hline Unexposed (controls) & 73 & 84 & 157 & 1.00 & & \\
\hline \multicolumn{7}{|l|}{ Exposed } \\
\hline Anesthetics & 65 & 25 & 90 & 2.99 & $1.71-5.23$ & 0.000 \\
\hline Cytostatics & 102 & 42 & 144 & 2.79 & $1.73-4.50$ & 0.000 \\
\hline Formaldehyde & 29 & 25 & 54 & 1.33 & $0.72-2.48$ & 0.361 \\
\hline Total & 269 & 176 & 445 & & & \\
\hline \multicolumn{7}{|l|}{ Female nurse (smoking) } \\
\hline Unexposed (controls) & 20 & 18 & 38 & 1.00 & & \\
\hline \multicolumn{7}{|l|}{ Exposed } \\
\hline Anesthetics & 27 & 16 & 43 & 1.52 & $0.63-3.69$ & 0.356 \\
\hline Cytostatics & 37 & 22 & 59 & 1.51 & $0.66-3.46$ & 0.326 \\
\hline Formaldehyde & 8 & 7 & 15 & 1.3 & $0.31-3.41$ & 0.963 \\
\hline Total & 92 & 63 & 155 & & & \\
\hline \multicolumn{7}{|c|}{ Female physician (non-smoking) } \\
\hline Unexposed (controls) & 14 & 12 & 26 & 1.00 & & \\
\hline \multicolumn{7}{|l|}{ Exposed } \\
\hline Anesthetics & 23 & 28 & 51 & 0.70 & $0.27-1.82$ & 0.468 \\
\hline Cytostatics & 18 & 5 & 23 & 3.9 & $0.88-10.83$ & 0.079 \\
\hline Formaldehyde & 5 & 6 & 11 & 0.71 & $0.17-2.94$ & 0.641 \\
\hline Total & 60 & 51 & 111 & & & \\
\hline \multicolumn{7}{|l|}{ Male physician (non-smoking) } \\
\hline Unexposed (controls) & 7 & 8 & 15 & 1.00 & & \\
\hline \multicolumn{7}{|l|}{ Exposed } \\
\hline Anesthetics & 20 & 9 & 29 & 2.54 & $0.70-9.17$ & 0.155 \\
\hline Cytostatics & 6 & 2 & 8 & 3.43 & $0.52-22.80$ & 0.202 \\
\hline Formaldehyde & 6 & 5 & 11 & 1.37 & $0.29-6.53$ & 0.692 \\
\hline Total & 39 & 24 & 63 & & & \\
\hline \multicolumn{7}{|l|}{ Male physician (smoking) } \\
\hline Unexposed (controls) & 1 & 4 & 5 & 1.00 & & \\
\hline \multicolumn{7}{|l|}{ Exposed } \\
\hline Anesthetics & 5 & 7 & 12 & 2.86 & $0.24-33.90$ & 0.406 \\
\hline Cytostatics & 2 & 0 & 2 & undefined & & 0.999 \\
\hline Formaldehyde & 11 & 2 & 13 & 22.00 & $1.54-314.29$ & 0.023 \\
\hline Total & 19 & 13 & 32 & & & \\
\hline \multicolumn{7}{|l|}{ Total data combined } \\
\hline Unexposed (controls) & 120 & 130 & 250 & 1.00 & & \\
\hline \multicolumn{7}{|l|}{ Exposed } \\
\hline Anesthetics & 152 & 95 & 247 & 1.73 & $1.21-2.48$ & 0.003 \\
\hline Cytostatics & 176 & 73 & 249 & 2.61 & $1.81-3.78$ & 0.000 \\
\hline Formaldehyde & 59 & 46 & 105 & 1.39 & $0.88-2.20$ & 0.160 \\
\hline Total & 507 & 344 & 851 & & & \\
\hline Binary logistic model & & & & & & \\
\hline Unexposed (controls) & & & & 1.00 & & \\
\hline Exposed (1 for yes) & & & & & & \\
\hline Anesthetics ( 1 for yes) & & & & 1.82 & $1.26-2.64$ & 0.002 \\
\hline Cytostatics ( 1 for yes) & & & & 2.61 & $1.80-3.79$ & 0.000 \\
\hline Formaldehyde (1 for yes) & & & & 1.37 & $0.85-2.19$ & 0.196 \\
\hline Gender (1 for man) & & & & 1.49 & $0.93-2.39$ & 0.101 \\
\hline Job (1 for physician) & & & & 0.74 & $0.51-1.8$ & 0.120 \\
\hline Smoking ( 1 for smoking) & & & & 0.89 & $0.64-1.22$ & 0.463 \\
\hline Age (years) & & & & 1.00 & $0.99-1.20$ & 0.539 \\
\hline
\end{tabular}


Table 3C. Binary logistic regression to describe relative risk of chromosome-type aberrations (CSA) for particular exposures in medical professions studied - stratified analysis for main confounders. Due to the low number of subjects, stratified results are not shown for smoking female physicians and for non-smoking or smoking male nurses. [OR=odds ratio; $95 \% \mathrm{Cl}=95 \%$ confidence interval]

\begin{tabular}{|c|c|c|c|c|c|c|}
\hline & \multicolumn{3}{|c|}{ Number of subjects } & \multirow[t]{3}{*}{$\mathrm{OR}$} & \multirow[t]{3}{*}{$95 \% \mathrm{Cl}$} & \multirow{3}{*}{$\begin{array}{c}\text { P-value } \\
\left(\mathrm{Chi}^{2}\right)\end{array}$} \\
\hline & \multicolumn{2}{|c|}{ Cells with CA/100 cell } & \multirow[t]{2}{*}{ Total } & & & \\
\hline & $\geq 1$ & $<1$ & & & & \\
\hline \multicolumn{7}{|l|}{ Female nurse (non-smoking) } \\
\hline Unexposed (controls) & 72 & 85 & 157 & 1.00 & & \\
\hline \multicolumn{7}{|l|}{ Exposed } \\
\hline Anesthetics & 70 & 20 & 90 & 4.13 & $2.30-7.44$ & 0.000 \\
\hline Cytostatics & 86 & 58 & 144 & 1.75 & $1.11-2.77$ & 0.016 \\
\hline Formaldehyde & 32 & 22 & 54 & 1.72 & $0.92-3.21$ & 0.091 \\
\hline Total & 260 & 185 & 445 & & & \\
\hline \multicolumn{7}{|l|}{ Female nurse (smoking) } \\
\hline Unexposed (controls) & 15 & 23 & 38 & 1.00 & & \\
\hline \multicolumn{7}{|l|}{ Exposed } \\
\hline Anesthetics & 32 & 11 & 43 & 4.46 & $1.73-11.47$ & 0.002 \\
\hline Cytostatics & 35 & 24 & 59 & 2.24 & $0.97-5.14$ & 0.058 \\
\hline Formaldehyde & 11 & 4 & 15 & 4.22 & $1.13-15.73$ & 0.032 \\
\hline Total & 93 & 62 & 155 & & & \\
\hline \multicolumn{7}{|c|}{ Female physician (non-smoking) } \\
\hline Unexposed (controls) & 13 & 13 & 26 & 1.00 & & \\
\hline \multicolumn{7}{|l|}{ Exposed } \\
\hline Anesthetics & 38 & 13 & 51 & 2.92 & $1.80-7.90$ & 0.034 \\
\hline Cytostatics & 13 & 10 & 23 & 1.30 & $0.42-4.1$ & 0.648 \\
\hline Formaldehyde & 4 & 7 & 11 & 0.57 & $0.13-2.43$ & 0.449 \\
\hline Total & 68 & 43 & 111 & & & \\
\hline \multicolumn{7}{|l|}{ Male physician (non-smoking) } \\
\hline Unexposed (controls) & 8 & 7 & 15 & 1.00 & & \\
\hline \multicolumn{7}{|l|}{ Exposed } \\
\hline Anesthetics & 18 & 11 & 29 & 1.43 & $0.41-5.6$ & 0.577 \\
\hline Cytostatics & 2 & 6 & 8 & 0.29 & $0.04-1.94$ & 0.202 \\
\hline Formaldehyde & 6 & 5 & 11 & 1.5 & $0.22-5.00$ & 0.951 \\
\hline Total & 34 & 29 & 63 & & & \\
\hline \multicolumn{7}{|l|}{ Male physician (smoking) } \\
\hline Unexposed (controls) & 0 & 5 & 5 & 1.00 & & \\
\hline \multicolumn{7}{|l|}{ Exposed } \\
\hline Anesthetics & 10 & 2 & 12 & undefined & & \\
\hline Cytostatics & 1 & 1 & 2 & undefined & & \\
\hline Formaldehyde & 5 & 8 & 13 & undefined & & \\
\hline Total & 16 & 16 & 32 & & & \\
\hline \multicolumn{7}{|l|}{ Total data combined } \\
\hline Unexposed (controls) & 111 & 139 & 250 & 1.00 & & \\
\hline \multicolumn{7}{|l|}{ Exposed } \\
\hline Anesthetics & 183 & 64 & 247 & 3.58 & $2.45-5.23$ & 0.000 \\
\hline Cytostatics & 146 & 103 & 249 & 1.78 & $1.24-2.53$ & 0.002 \\
\hline Formaldehyde & 59 & 46 & 105 & 1.61 & $1.10-2.54$ & 0.043 \\
\hline Total & 499 & 352 & 851 & & & \\
\hline Binary logistic model & & & & & & \\
\hline Unexposed (controls) & & & & 1.00 & & \\
\hline Exposed (1 for yes) & & & & & & \\
\hline Anesthetics (1 for yes) & & & & 3.78 & $2.54-5.60$ & 0.000 \\
\hline Cytostatics ( 1 for yes) & & & & 1.68 & $1.17-2.41$ & 0.005 \\
\hline Formaldehyde ( 1 for yes) & & & & 1.57 & $0.98-2.53$ & 0.061 \\
\hline Gender ( 1 for man) & & & & 0.77 & $0.48-1.23$ & 0.270 \\
\hline Job (1 for physician) & & & & 0.85 & $0.58-1.24$ & 0.389 \\
\hline Smoking ( 1 for smoking) & & & & 0.98 & $0.70-1.36$ & 0.894 \\
\hline Age (years) & & & & 1.2 & $1.00-1.30$ & 0.043 \\
\hline
\end{tabular}




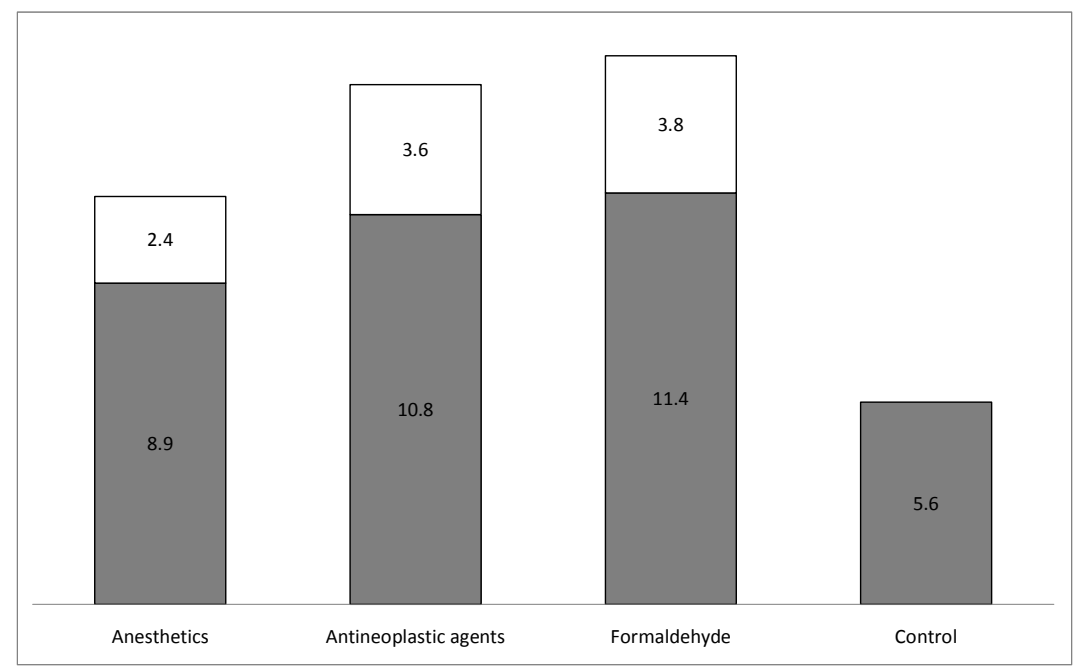

Figure 2. Proportion (shown as percentage inside each column) of subjects with chromatid-type exchanges (white columns) and chromosome-type exchanges (grey columns) in individual exposure categories and in controls exposed to various genotoxic compounds in specialized hospital wards, comprising several medical professions. It is noteworthy that potentially harmful exposures in medical care may concern relatively large teams and, thus, represent a considerable health risk. The first at risk are anesthesiology workers exposed to volatile anesthetics. Several papers have reported an increase of CATot among operating rooms workers (38-40), and the present study, based on a large group of 247 subjects, strongly supports the earlier findings. The increased CA frequency may be caused by an accumulation of volatile anesthetics in operating rooms, due to inappropriate conditions such as ineffective or inadequate air circulation and ventilation. Epidemiologic studies have disclosed markedly higher concentrations of anesthetics in operating rooms without effective air circulation (41). More than a ten-fold hourly exchange of air in operating rooms resulted in a significant decrease of halothane concentration (42). According to Slovak law, the average workplace air concentration of anesthetics should not exceed $80 \mathrm{mg} / \mathrm{m}^{3}$ (10 ppm), and short-term concentrations should not exceed $20 \mathrm{ppm}\left(150 \mathrm{mg} / \mathrm{m}^{3}\right)$. In the anesthesiology units included in the present study, the concentrations of anesthetics (sevoflurane in particular) in operating rooms were assessed during 2011, and the average concentration of sevoflurane was found to be more than two-fold higher than the limit (ranging from $64.2-483.9 \mathrm{mg} / \mathrm{m}^{3}$ with an average of $200.3 \mathrm{mg}$ / $\mathrm{m}^{3}$ or $\left.25 \mathrm{ppm}\right)$.

In the present study, the CATot frequencies in the control population were in a range similar to what we described earlier (43). Exposures to anesthetics and cytostatics were associated with an increase in both CTA and CSA. For cytostatics, the induction of CTA was expected because many of the anti-cancer drugs used were S-dependent clastogens (cyclophosphamide and ifosfamide) $(44,45)$. The increase in CSA observed in the cytostatics exposure group may not primarily have been due to true radiomimetic drugs, since bleomycin was only marginally used, but could rather have reflected derived-type CSA formed from CTA that had occurred in an earlier division in vivo or effects of agents able to prevent G1 DNA repair (cytarabine). The possible genotoxic mechanisms of anesthetics are poorly understood, although oxidative DNA damage (isoflurane, sevoflurane, and nitrous oxide) and modification of N7-position of guanine (isoflurane) have been suggested (16-18). The present study assessed the clastogenic effects of chronic exposures to mixtures of chemicals with different modes of action, and very little is known about the effects of such exposures on peripheral T-lymphocytes with variable half lives in the body.

The higher frequencies of chromosomal damage among female compared to male physicians were possibly associated with higher exposures of women to the individual genotoxic contaminants in the hospital environment, as apparent from the stratified data analysis. There was no general difference between the sexes for any type of CATot, in accordance with earlier studies $(34,44,45)$, in contrast to micronuclei which showed a higher rate among women in a number of studies (44).

Most antineoplastic agents exhibit genotoxic, mutagenic, or carcinogenic effects (30). They produce irregular cell division, damage intercellular surroundings, and induce cellular death. Increased frequencies of CATot, $\mathrm{SCE}$, and micronuclei after occupational exposure to antineoplastic agents have been previously reported (1, 21, 46, 47). However, these studies have been conducted on a limited number of subjects. Chromosomal damage related to exposure to antineoplastic drugs may also arise as a consequence of secondary oxidative stress (48). Several reports investigated the extent of chro- 
mosomal damage or other types of genotoxic effects in association with various routes of exposure, such as inhalation or skin absorption, with and without the use of protective means (49-51). Moretti et al (52) recently proposed a protocol for epidemiological studies by using an integrated environmental and biological monitoring approach for investigating the genotoxic effects of antineoplastic drugs. Although our study, reporting elevated chromosomal damage among 249 nurses and physicians, provides robust and convincing evidence for health risks in oncology units, individual exposure to cytostatics could not be determined and only information on the total use of cytostatics in 2011 (cyclophosphamide $930 \mathrm{~g}$, cytarabine $520 \mathrm{~g}$, rituximab $420 \mathrm{~g}$, fluoruracil $270 \mathrm{~g}$, and ifosfamide $270 \mathrm{~g}$ ) were available.

Although formaldehyde is a proven chemical carcinogen (13), it is still frequently used in histopathology laboratories worldwide as a fixative and tissue preservative. Occupational exposure to formaldehyde was found to increase the frequency of CATot, SCE, and micronuclei in PBL in a number of studies $(3,6,8-10)$, probably due to a long-term effect of the low doses that reach blood cells. Despite the fact that formaldehyde exposure was associated with lower frequencies of CATot, CTA, and CSA than exposure to anesthetics and antineoplastic drugs in our population, formaldehyde represents a serious health risk particularly as the frequencies of chromatid and chromosome exchanges were three-fold higher among the formaldehyde-exposed workers than the controls. Formaldehyde concentration at the department of pathologic anatomy, measured once a year, was $0.32 \mathrm{mg} / \mathrm{m}^{3}$ (range $0.14-0.66 \mathrm{mg} / \mathrm{m}^{3}$ ), which is below the Slovakian PEL for formaldehyde (average concentration of $0.37 \mathrm{mg} / \mathrm{m}^{3}$, short-term concentration $0.74 \mathrm{mg} / \mathrm{m}^{3}$ ).

Regarding the effect of main confounders on the level of chromosomal damage, higher frequencies of total CATot as well as CSA were found among female nurses compared to medical doctors. A similar finding has been published earlier (53). The explanation for the difference in chromosomal damage between the nurses and the doctors may be the longer and higher exposure of the former group; however, personal dosimetry was not available to discern if this was the true reason. We observed a slightly increased frequency of CATot among smokers, which did not reach statistical significance; this potential confounder did not contribute to the presented binary logistic models. The small influence of smoking on CATot was only apparent among the control individuals but not the exposed as if the effect appeared to be masked by the occupational exposure.

\section{Concluding remarks}

Our findings indicate that the presence of genotoxic compounds in operating rooms, oncological units, and pathological departments results in a significant increase of chromosomal damage (impairment of chromosomal integrity) among the medical workers employed in these facilities. Since CA are considered predictive of cancer risk, effective measures aimed at the reduction of exposures should be imposed.

Further studies should focus on the assessment of the relationship between individual exposure and risk among the medical personnel and the identification of the reason for the increased level of CATot among females. Additional information about DNA damage that could be associated with CA, and about individual ability to deal with this damage, could be obtained by determining DNA damage markers, such as DNA adducts or DNA double-strand breaks, and DNA repair capacity (54). Such studies may help in understanding the genotoxic burden present in the hospital environment.

\section{Acknowledgments}

This work was supported by project "Carcinogenic and toxic metals in working environment" (code:26220220111), co-financed by EU sources and the European Regional Development Fund, Grant 2007/48-UK-13 from Slovak Ministry of Health, Grant VEGA1/0576/10 from Slovak Ministry of Education and Prvouk-P27/LF1/1 from Ministry of Education, Youth and Sport, Czech Republic (First Medical Faculty, Charles University, Prague, Czech Republic as a recipient).

We are greatly indebted to Professor AT Natarajan for his valuable suggestions.

The authors declare no conflict of interest that would prejudice the impartiality of this study.

\section{References}

1. Cavallo D, Ursini CL, Omodeo-Sale E, Iavicoli S. Micronucleus induction and FISH analysis in buccal cells and lymphocytes of nurses administering antineoplastic drugs. Mutat Res. 2007 Mar 30;628(1):11-8. http://dx.doi. org/10.1016/j.mrgentox.2006.10.014.

2. Rekhadevi PV, Sailaja N, Chandrasekhar M, Mahboob M Rahman MF, Grover P. Genotoxicity assessment in oncology nurses handling anti-neoplastic drugs. Mutagenesis. 2007 Nov;22(6):395-401. http://dx.doi.org/10.1093/mutage/ gem032.

3. Schmid O, Speit G. Genotoxic effects induced by formaldehyde in human blood and implications for the interpretation of biomonitoring studies. Mutagenesis. 2007 Jan;22(1):69-74. http://dx.doi.org/10.1093/mutage/gel053.

4. Neuss S, Speit G. Further characterization of the genotoxicity 
of formaldehyde in vitro by the sister chromatid exchange test and co-cultivation experiments. Mutagenesis. 2008 Sep;23(5):355-7. http://dx.doi.org/10.1093/mutage/gen025.

5. Wiesner G, Schiewe-Langgartner F, Lindner R, Gruber M. Increased formation of sister chromatid exchanges, but not of micronuclei, in anaesthetists exposed to low levels of sevoflurane. Anaesthesia. 2008 Aug;63(8):861-4. http:// dx.doi.org/10.1111/j.1365-2044.2008.05498.x.

6. Jakab MG, Klupp T, Besenyei K, Biro A, Major J, Tompa A. Formaldehyde-induced chromosomal aberrations and apoptosis in peripheral blood lymphocytes of personnel working in pathology departments. Mutat Res. 2010 Apr 30;698(1-2):117. http://dx.doi.org/10.1016/j.mrgentox.2010.02.015.

7. Gulten T, Evke E, Ercan I, Evrensel T, Kurt E, Manavoglu O. Lack of genotoxicity in medical oncology nurses handling antineoplastic drugs: effect of work environment and protective equipment. Work. 2011 Jan;39(4):485-9.

8. Costa S, Pina C, Coelho P, Costa C, Silva S, Porto B, et al. Occupational exposure to formaldehyde: genotoxic risk evaluation by comet assay and micronucleus test using human peripheral lymphocytes. J Toxicol Environ Health A. 2011;74(15-16):1040-51. http://dx.doi.org/10.1080/152873 94.2011 .582293 .

9. Ladeira C, Viegas S, Carolino E, Prista J, Gomes MC, Brito M. Genotoxicity biomarkers in occupational exposure to formaldehyde--the case of histopathology laboratories. Mutat Res. 2011 Mar 18;721(1):15-20. http://dx.doi.org/10.1016/j. mrgentox.2010.11.015.

10. Santovito A, Schiliro T, Castellano S, Cervella P, Bigatti MP, Gilli G, et al. Combined analysis of chromosomal aberrations and glutathione S-transferase M1 and T1 polymorphisms in pathologists occupationally exposed to formaldehyde. Arch Toxicol. 2011 Oct;85(10):1295-302. http://dx.doi. org/10.1007/s00204-011-0668-3.

11. Jaloszynski P, Kujawski M, Wasowicz M, Szulc R, Szyfter K. Genotoxicity of inhalation anesthetics halothane and isoflurane in human lymphocytes studied in vitro using the comet assay. Mutat Res. 1999 Feb 19;439(2):199-206. http://dx.doi. org/10.1016/S1383-5718(98)00195-8.

12. Karpinski TM, Kostrzewska-Poczekaj M, Stachecki I, Mikstacki A, Szyfter K. Genotoxicity of the volatile anaesthetic desflurane in human lymphocytes in vitro, established by comet assay. J Appl Genet. 2005;46(3):319-24.

13. International Agency for Research on Cancer (IARC). Formaldehyde, 2-butoxyethanol and 1-tert-butoxypropan-2-ol. IARC Monogr Eval Carcinog Risks Hum. 2006;88:1-478

14. Rozgaj R, Kasuba V, Brozovic G, Jazbec A. Genotoxic effects of anaesthetics in operating theatre personnel evaluated by the comet assay and micronucleus test. Int $\mathrm{J}$ Hyg Environ Health,2009 Jan;212(1):11-7. http://dx.doi.org/10.1016/j. ijheh.2007.09.001.

15. Lewinska D, Stepnik M, Krajewski W, Arkusz J, Stanczyk M, Wronska-Nofer T. Increased incidence of micronuclei assessed with the micronucleus assay and the fluorescence in situ hybridization (FISH) technique in peripheral blood lymphocytes of nurses exposed to nitrous oxide. Mutat Res.
2005 Mar 7;581(1-2):1-9. http://dx.doi.org/10.1016/j. mrgentox.2004.10.018.

16. Braz MG, Mazoti MA, Giacobino J, Braz LG, Golim Mde A, Ferrasi AC, et al. Genotoxicity, cytotoxicity and gene expression in patients undergoing elective surgery under isoflurane anaesthesia. Mutagenesis. 2011 May;26(3):415-20. http://dx.doi.org/10.1093/mutage/geq109.

17. Wronska-Nofer T, Nofer JR, Jajte J, Dziubaltowska E, Szymczak W, Krajewski W, et al. Oxidative DNA damage and oxidative stress in subjects occupationally exposed to nitrous oxide (N(2)O). Mutat Res. 2012 Mar 1;731(1-2):58-63. http:// dx.doi.org/10.1016/j.mrfmmm.2011.10.010.

18. Braz MG, Braz LG, Barbosa BS, Giacobino J, Orosz JE, Salvadori DM, et al. DNA damage in patients who underwent minimally invasive surgery under inhalation or intravenous anesthesia. Mutat Res. 2011 Dec 24;726(2):251-4. http:// dx.doi.org/10.1016/j.mrgentox.2011.09.007.

19. Gabano E, Ravera M, Osella D. The drug targeting and delivery approach applied to pt-antitumour complexes. A coordination point of view. Curr Med Chem. 2009;16(34):4544-80. http:// dx.doi.org/10.2174/092986709789760661.

20. International Agency for Research on Cancer (IARC). Agents classified by the IARC Monographs. IARC Monogr Eval Carcinog Risks Hum. 2012;vol:1-104.

21. Musak L, Vodicka P, Klimentova G, Soucek P, Hanova M, Mikulkova R, et al. Chromosomal damage and polymorphisms of DNA repair genes XRCC1 and XRCC3 in workers exposed to cytostatics. Neuro Endocrinol Lett. 2006 Dec;27 Suppl 2:57-60.

22. Tompa A, Magyar B, Toth F, Biro A, Fodor Z, Jakab M, et al. [The state of health of oncology nurses characterized by genetic and immunotoxicologic biomarkers]. Magy Onkol. 2006;50(2):153-61.

23. Testa A, Giachelia M, Palma S, Appolloni M, Padua L, Tranfo G, et al. Occupational exposure to antineoplastic agents induces a high level of chromosome damage. Lack of an effect of GST polymorphisms. Toxicol Appl Pharmacol. 2007 Aug 15;223(1):46-55. http://dx.doi.org/10.1016/j. taap.2007.05.006.

24. Cornetta T, Padua L, Testa A, Ievoli E, Festa F, Tranfo G, et al. Molecular biomonitoring of a population of nurses handling antineoplastic drugs. Mutat Res. 2008 Feb 1;638(1-2):75-82. http://dx.doi.org/10.1016/j.mrfmmm.2007.08.017.

25. Kopjar N, Garaj-Vrhovac V, Kasuba V, Rozgaj R, Ramic S, Pavlica V, et al. Assessment of genotoxic risks in Croatian health care workers occupationally exposed to cytotoxic drugs: a multi-biomarker approach. Int J Hyg Environ Health. 2009 Jul;212(4):414-31. http://dx.doi.org/10.1016/j. ijheh.2008.10.001.

26. Boughattas AB, Bouraoui S, Debbabi F, El Ghazel H, Saad A, Mrizak N. Évaluation du risque génotoxique chez les infirmiers manipulant les cytostatiques [Genotoxic risk assessment of nurses handling antineoplastic drugs]. Ann Biol Clin (Paris.) 2010 Sep-Oct;68(5):545-53.

27. Zeller J, Neuss S, Mueller JU, Kuhner S, Holzmann K, Hogel 
$\mathrm{J}$, et al. Assessment of genotoxic effects and changes in gene expression in humans exposed to formaldehyde by inhalation under controlled conditions. Mutagenesis. 2011 Jul;26(4):55561. http://dx.doi.org/10.1093/mutage/ger016.

28. Speit G, Ladeira C, Linsenmeyer R, Schutz P, Hogel J. Reevaluation of a reported increased micronucleus frequency in lymphocytes of workers occupationally exposed to formaldehyde. Mutat Res. 2012 May 15;744(2):161-6. http:// dx.doi.org/10.1016/j.mrgentox.2012.02.009.

29. US Department of Health and Human Services, Public Health Service. National Toxicology Program. Final Report on Carcinogens Background Document for Formaldehyde. Rep Carcinog Backgr Doc. 2010 Jan;(10-5981): i-512.

30. US Department of Health and Human Services, Public Health Service. National Toxicology Program. $12^{\text {th }}$ Report on Carcinogens. Rep Carcinog. 2011;12:iii-499.

31. Hagmar L, Stromberg U, Bonassi S, Hansteen IL, Knudsen LE, Lindholm C, et al. Impact of types of lymphocyte chromosomal aberrations on human cancer risk: results from Nordic and Italian cohorts. Cancer Res. 2004 Mar 15;64(6):2258-63. http://dx.doi.org/10.1158/0008-5472.CAN-03-3360.

32. Bonassi S, Norppa H, Ceppi M, Stromberg U, Vermeulen $\mathrm{R}$, Znaor A, et al. Chromosomal aberration frequency in lymphocytes predicts the risk of cancer: results from a pooled cohort study of 22358 subjects in 11 countries. Carcinogenesis. 2008 Jun;29(6):1178-83. http://dx.doi. org/10.1093/carcin/bgn075.

33. Vodicka P, Polivkova Z, Sytarova S, Demova H, Kucerova M, Vodickova L, et al. Chromosomal damage in peripheral blood lymphocytes of newly diagnosed cancer patients and healthy controls. Carcinogenesis. 2010 Jul;31(7):1238-41. http:// dx.doi.org/10.1093/carcin/bgq056.

34. Musak L, Soucek P, Vodickova L, Naccarati A, Halasova E, Polakova V, et al. Chromosomal aberrations in tire plant workers and interaction with polymorphisms of biotransformation and DNA repair genes. Mutat Res. 2008 May 10;641(1-2):36-42. http://dx.doi.org/10.1016/j. mrfmmm.2008.02.007.

35. Albertini RJ, Anderson D, Douglas GR, Hagmar L, Hemminki K, Merlo F, et al. IPCS guidelines for the monitoring of genotoxic effects of carcinogens in humans. International Programme on Chemical Safety. Mutat Res. 2000 Aug;463(2):111-72. http://dx.doi.org/10.1016/S13835742(00)00049-1.

36. Norppa H, Bonassi S, Hansteen IL, Hagmar L, Stromberg $\mathrm{U}$, Rossner P, et al. Chromosomal aberrations and SCEs as biomarkers of cancer risk. Mutat Res. 2006 Aug 30;600(12):37-45. http://dx.doi.org/10.1016/j.mrfmmm.2006.05.030.

37. Sram RJ, Rossner P, Smerhovsky Z. Cytogenetic analysis and occupational health in the Czech Republic. Mutat Res. 2004 Jan;566(1):21-48. http://dx.doi.org/10.1016/S13835742(03)00034-6.

38. Rozgaj R, Kasuba V, Peric M. Chromosome aberrations in operating room personnel. Am J Ind Med. 1999 Jun;35(6):642-6. http://dx.doi.org/10.1002/(SICI)10970274(199906)35:6<642::AID-AJIM11>3.0.CO;2-N.

39. Rozgaj R, Kasuba V, Jazbec A. Preliminary study of cytogenetic damage in personnel exposed to anesthetic gases. Mutagenesis. 2001 Mar;16(2):139-43. http://dx.doi. org/10.1093/mutage/16.2.139.

40. Natarajan AT. Chromosome aberrations: past, present and future. Mutat Res. 2002 Jul 25;504(1-2):3-16. http://dx.doi. org/10.1016/S0027-5107(02)00075-1

41. Wiesner G, Harth M, Hoerauf K, Szulc R, Jurczyk W, Sobczynski $\mathrm{P}$, et al. Occupational exposure to inhaled anaesthetics: a follow-up study on anaesthetists of an eastern European university hospital. Acta Anaesthesiol Scand. 2000 Aug;44(7):804-6. http://dx.doi.org/10.1034/j.13996576.2000.440706.x.

42. Wiesner G, Hoerauf K, Schroegendorfer K, Sobczynski P, Harth M, Ruediger HW. High-level, but not low-level, occupational exposure to inhaled anesthetics is associated with genotoxicity in the micronucleus assay. Anesth Analg. 2001 Jan;92(1):118-22. http://dx.doi.org/10.1097/00000539200101000-00023.

43. Vodicka P, Kumar R, Stetina R, Sanyal S, Soucek P, Haufroid $\mathrm{V}$, et al. Genetic polymorphisms in DNA repair genes and possible links with DNA repair rates, chromosomal aberrations and single-strand breaks in DNA. Carcinogenesis. 2004;25(5):757-63. http://dx.doi.org/10.1093/carcin/ bgh064.

44. Hagmar L, Stromberg U, Tinnerberg H, Mikoczy Z. Epidemiological evaluation of cytogenetic biomarkers as potential surrogate end-points for cancer. IARC Sci Publ. 2004;(157):207-15.

45. Rossner P, Boffetta P, Ceppi M, Bonassi S, Smerhovsky Z, Landa $\mathrm{K}$, et al. Chromosomal aberrations in lymphocytes of healthy subjects and risk of cancer. Environ Health Perspect. 2005 May;113(5):517-20. http://dx.doi.org/10.1289/ ehp.6925.

46. Burgaz S, Karahalil B, Canhi Z, Terzioglu F, Ancel G, Anzion RB, et al. Assessment of genotoxic damage in nurses occupationally exposed to antineoplastics by the analysis of chromosomal aberrations. Hum Exp Toxicol. 2002 Mar;21(3):129-35. http://dx.doi. org/10.1191/0960327102ht230oa.

47. Bilban M, Jakopin CB, Ogrinc D. Cytogenetic tests performed on operating room personnel (the use of anaesthetic gases). Int Arch Occup Environ Health. 2005 Feb;78(1):60-4. http:// dx.doi.org/10.1007/s00420-004-0579-1.

48. Rombaldi F, Cassini C, Salvador M, Saffi J, Erdtmann B. Occupational risk assessment of genotoxicity and oxidative stress in workers handling anti-neoplastic drugs during a working week. Mutagenesis. 2009 Mar;24(2):143-8. http:// dx.doi.org/10.1093/mutage/gen060.

49. Fransman W, Vermeulen R, Kromhout H. Dermal exposure to cyclophosphamide in hospitals during preparation, nursing and cleaning activities. Int Arch Occup Environ Health. 2005 Jun;78(5):403-12. http://dx.doi.org/10.1007/s00420-0040595-1.

50. Fransman W, Roeleveld N, Peelen S, de Kort W, 
Kromhout H, Heederik D. Nurses with dermal exposure to antineoplastic drugs: reproductive outcomes. Epidemiology. 2007 Jan;18(1):112-9. http://dx.doi.org/10.1097/01. ede.0000246827.44093.c1.

51. Connor TH. Hazardous anticancer drugs in health care: environmental exposure assessment. Ann N Y Acad Sci. 2006 Sep;1076:615-23. http://dx.doi.org/10.1196/ annals.1371.021.

52. Moretti M, Bonfiglioli R, Feretti D, Pavanello S, Mussi F, Grollino MG, et al. A study protocol for the evaluation of occupational mutagenic/carcinogenic risks in subjects exposed to antineoplastic drugs: a multicentric project. BMC Public Health. 2011;11:195. http://dx.doi.org/10.1186/1471-245811-195.
53. Prokes B. Kretanje nivoa "izgubljenog" halotana u operacionim salama klinike za ginekologiju i akuserstvo-preliminarni rezultati. [Levels of "waste" halothane in operating rooms at gynecologic and obstetrical clinics--preliminary results]. Med Pregl.1998 Nov-Dec;51(11-12):532-6.

54. Slyskova J, Korenkova V, Collins AR, Prochazka P, Vodickova L, Svec J, et al. Functional, Genetic, and Epigenetic Aspects of Base and Nucleotide Excision Repair in Colorectal Carcinomas. Clin Cancer Res. 2012 Nov 1;18(21):5878-87. http://dx.doi. org/10.1158/1078-0432.CCR-12-1380.

Received for publication: 15 June 2012 